\title{
Hand-Made, Three-Dimensional Molecular Model for Active Inorganic Chemistry Learning
}

\author{
Elahe Keshavarz \\ Department of Sciences, Farhangian University, Rasht, Iran \\ Email: iyc.2011@yahoo.com
}

How to cite this paper: Keshavarz, E. (2018). Hand-Made, Three-Dimensional Molecular Model for Active Inorganic Chemistry Learning. Creative Education, 9, 1168-1173. https://doi.org/10.4236/ce.2018.97086

Received: January 19, 2018

Accepted: June 22, 2018

Published: June 25, 2018

Copyright (C) 2018 by author and Scientific Research Publishing Inc. This work is licensed under the Creative Commons Attribution International License (CC BY 4.0).

http://creativecommons.org/licenses/by/4.0/

\begin{abstract}
The use of molecular model in education has demonstrated its importance due to its positive impact on the teaching and learning process. It is obvious that hand-made tools have considerable importance in science education. This study suggests for employing three-dimensional molecular model in teaching and appraising chemistry skills and knowledge in high schools and universities. This paper presents three molecular models for unit cells of cubic system.
\end{abstract}

Keywords

Active Learning, Crystal System, Inorganic Chemistry, Molecular Model

\section{Introduction}

High school and chemistry students are educated many concepts that need the engagement of spatial abilities. The purpose of learning is not just for chemical literacy but for the understanding and usage of scientific knowledge and skills for sustainable expansion of science of the student (Dawson \& Venville, 2010). Students find this to be a challenging duty, and when considering that these skills are heavily relied upon in high school and university both in general and inorganic chemistry, it may well be one of the most considerable conceptual problems for germinating chemistry teachers to overcome. As such, mastering these skills will permit students a firm foundation upon which to make higher level skills.

On the other hand, there is ample evidence that learning is enhanced through active experiences. This is especially true when spatial concepts are involved that are difficult to visualize and understand abstractly, even with the help of simulations and virtual models (Tatli \& Ayas, 2013; Shah \& Khan, 2015; Alsuitanny, 
Nouby, \& Al-Enazi, 2014; Moraru, Stoica, \& Popescu, 2011). A study of knowledge retention showed that little knowledge is maintained when only abstract conceptualization is involved, but a lot of knowledge is retained when the concrete experience is involved (Stice, 1987).

In fact, a serious problem is related to the lack of the use of the inquiry approaches in science lessons (Snyder \& Sullivan, 1995; Klymkowsky \& Garvin-Doxas, 2008; Larkin, 2012; Özmen, 2004; Thompson \& Logue, 2006; Andelkovic, Andelkovic, \& Nikolic, 2015). Science teachers should emphasize methods for providing students with opportunities to do science, in addition to learning the facts and concepts of science (Okorie \& Agah, 2014; Martin-Blas \& Serrano-Fernandez, 2009). Therefore, activities supporting scientific curricular goals should be planned and implemented to promote student-centred, inquiry-based learning.

Many educators recognize the importance of hands-on models (Dean, Ewan, \& Mclndoe, 2016; Isman, Yaratan, \& Caner, 2007) and have designed and constructed physical demonstration models for teaching. In many universities and schools, one can often see many teaching molecular models for teaching chemistry. For example, since there is no direct relation between the formula of a compound and the shape of its molecules, the shapes of many molecules can be forecasted from their Lewis structures, however, with a model expanded about many years ago, known as the (VSEPR) valence-shell electron-pair repulsion theory. Many types of models have been used to help visualize the shapes foretold by VSEPR theory. However, many of these instances do not focus on crystal systems in inorganic chemistry. Therefore, in continuation of our recent works (Keshavarz, Alizadeh, \& Alizadeh, 2017; Keshavarz \& Malekzade, 2015; Keshavarz \& Zare, 2017), in this study placing hand-made three-dimensional molecular model within the context of chemistry content, makes inorganic chemistry more available, and sets the phase for the expansion of students' understandings of the relationship between invisible particles and science learning.

Our workhouse newly has constructed three-dimensional plastic model of unit cells of cubic system to teach chemistry students about molecular shape and geometry in inorganic chemistry.

\section{Description of the Original Model}

Inorganic chemistry is a subject with often considered difficult and boring because the subject is related to phenomena that are unobservable, for example, students cannot see atomic structure. Understanding the relationship between a two-dimensional representation and the corresponding three-dimensional thing is an acute concept in chemistry. For example, structural features of solids in general and inorganic chemistry, often educated in chemistry courses needs students to have the capability to take a two-dimensional delegation on the page and transform it into a three-dimensional thing in their minds.

One part of solids is crystalline solids that have defined shapes because their 
particles occur in an orderly arrangement. The particles in a crystal are packed tightly in an orderly, three-dimensional array. There are seven crystal systems and 14 types of unit cells that occur in nature. Unit cells result from the ways atoms pack together. The first and simplest crystal system is cubic system. The cubic systems are three types of cubic unit cells. In the primitive cubic unit cell, the centers of eight identical particles define the corners of a cube (Figure 1(a)). On the other hand, in the body centered cubic unit cell, identical particles lie at each corner and in the center of the cube. Each particle is surrounded by eight nearest neighbors, four above and four below (Figure 1(b)). In the face centered cubic unit cell (Figure 1(c)), identical particles lie at each corner and in the center of each face but not in the center of the cube.

Our experience of teaching according to the original model makes learning crystalline solids enjoyable by employing innovative hand-made model (Figure 2).

The resulting hand-made shapes were designed and pieces combine into the corresponding crystal shape. In fact, we observed in our teaching practice that the best results were achieved when the user drew the circles for the atoms first, then joined them together by drawing in the bonds, a process that not only makes them more visually pleasing, but also adds a factor of strength to the model. The student would then hold the pieces in place and fix them together. For example, to produce a primitive cubic model, students would take eight balls and then join them together and fix them into place using plastic rod. The result is beautiful, colored 3D models of the cubic systems (Figure 3).

These models have the potential to change learning problem from abstract to real to make it easier to understand.

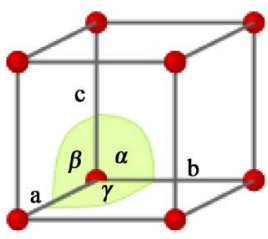
primitive

(a)

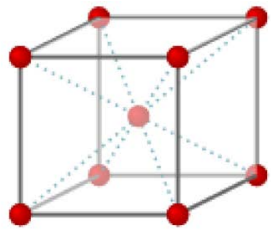

body centered

(b)

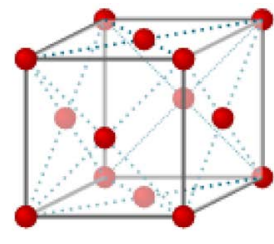

face centered

(c)

Figure 1. Unit cells of cubic system, http://www.physics-in-a-nutshell.com.

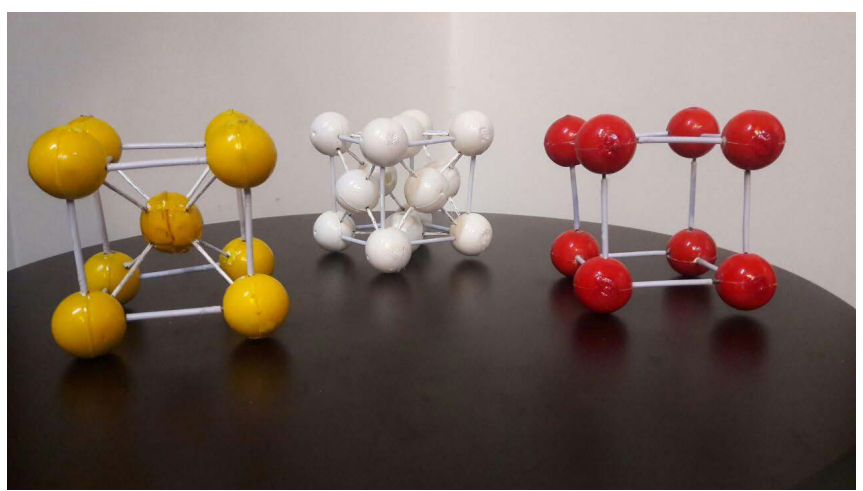

Figure 2. Hand-made molecular models for unit cells of cubic system. 

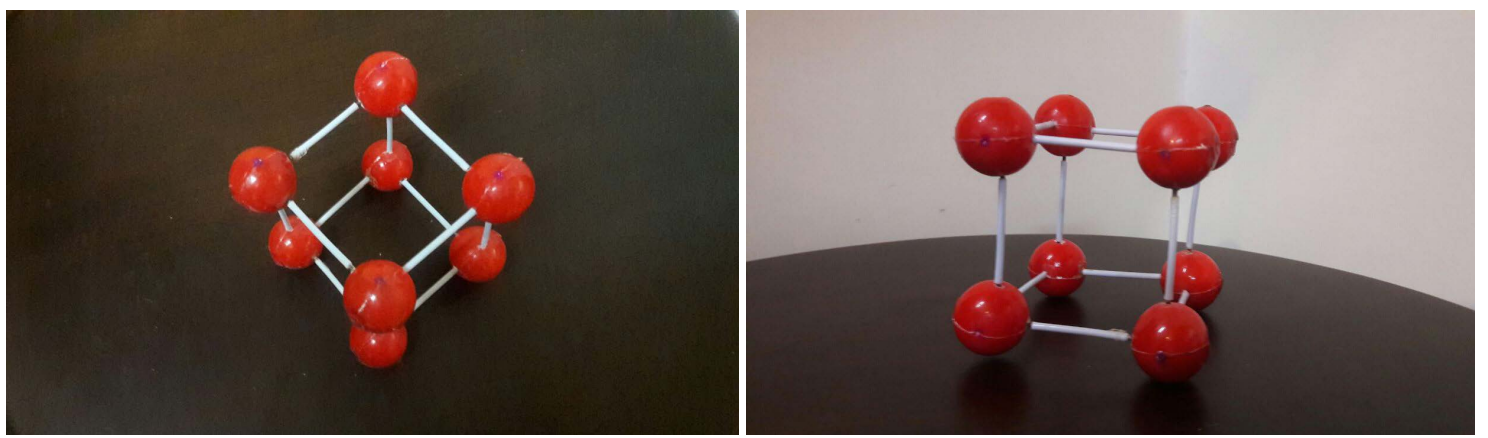

(a)
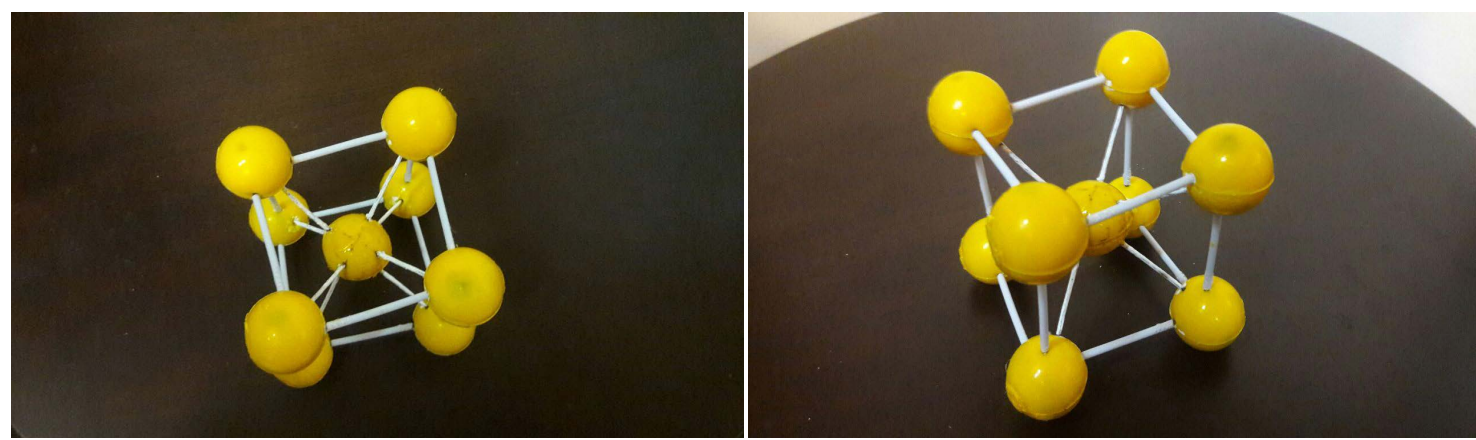

(b)
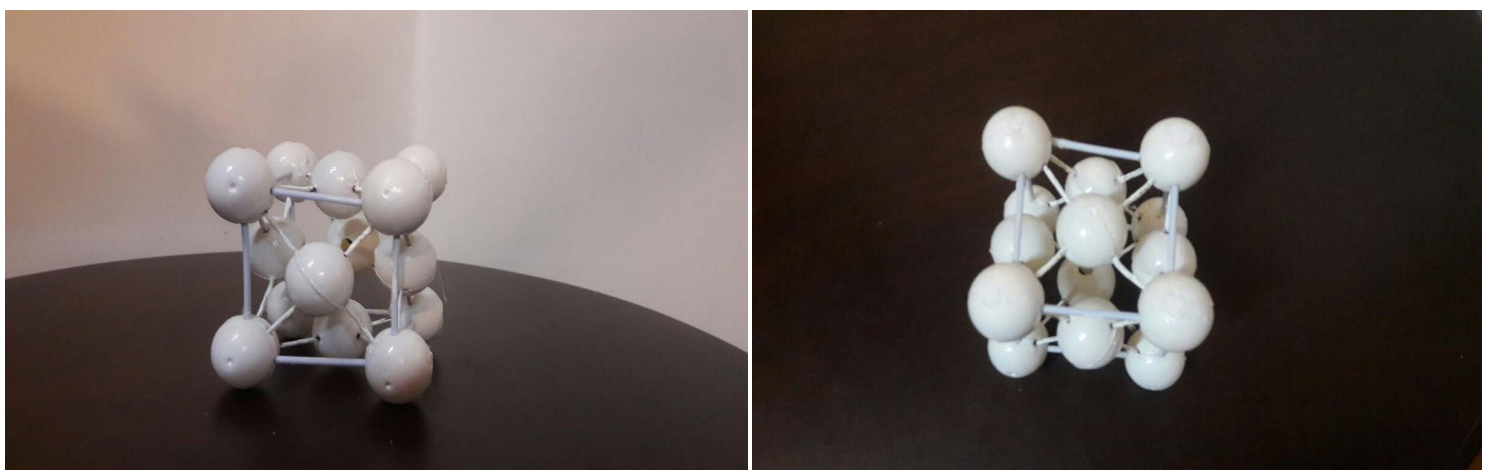

(c)

Figure 3. (a) Hand-Made primitive cubic unit cell; (b) Hand-Made body centered cubic unit cell; (c) Hand-Made face centered cubic unit cell.

\section{Conclusion}

It can be said that the teaching science has been traditional, but hand-on developments have affected chemistry education. The application of hand-made 3D molecular model has the potential to provide a fresh and unique way for students to learn about solid shapes. Not only could this to be a fun and engage learning exercise for students, but the students could also keep their models afterward as the raw material, plastic, is inexpensive. We envisage that this would result in students being likely to share their experience with friends and family, potentially promoting a more positive attitude toward learning crystal systems.

\section{Acknowledgements}

The author would like to thank Farhangian University. This work is dedicated to 
authors' father.

\section{References}

Alsuitanny, Y. A., Nouby, A. M., \& Al-Enazi, T. T. (2014). Effects of Using Simulation in E-Learning Programs on Misconceptions and Motivations towards Learning. International Journal of Scientific \& Technology Research, 5, 40-51.

Andelkovic, T., Andelkovic, D., \& Nikolic, Z. S. (2015). The Impact of E-Learning in Chemistry Education (pp. 24-25). 6th International Conference on e-Learning, Belgrade, Serbia: E-Learning Industry.

Dawson, V. M., \& Venville, G. (2010). Teaching Strategies for Developing Students' Argumentation Skills about Socioscientific Issues in High School Genetics. Research in Science Education, 40, 133-148. https://doi.org/10.1007/s11165-008-9104-y

Dean, N. L., Ewan, C., \& Mclndoe, J. (2016). Applying Hand-Held 3D Printing Technology to the Teaching of VSEPR Theory. Journal of Chemical Education, 93, 1660-1662. https://doi.org/10.1021/acs.jchemed.6b00186

Isman, A., Yaratan, H., \& Caner, H. (2007). How Technology Is Integrated into Science Education in a Developing Country: North Cyprus Case. The Turkish Online Journal of Educational Technology, 6, Article 5.

Keshavarz, E., \& Malekzade, F. (2015). Microscale Laboratory: Creating Effective Learning Environments toward Student Teachers in Primary Education. International Journal of Technical Research and Applications, 30, 56-58.

Keshavarz, E., \& Zare, S. (2017). The Impact of a New Chemistry Software on Development of Students' Skills in Laboratory Lesson (pp. 8916-8918). Proceedings from iCERi'2017: 10th International Conference of Education, Research AND Innovation, Spain, IATED.

Keshavarz, E., Alizadeh, A., \& Alizadeh, R. (2017). High School Students' Ideas about Concepts Related to Chemistry and Physics: An Exploration of Common Misconceptions in Science. IOSR Journal of Research \& Method in Education, 7, 71-74.

Klymkowsky, M. W., \& Garvin-Doxas, K. (2008). Recognizing Student Misconceptions through Ed's Tools and the Biology Concept Inventory. PLoS Biology, 6, 0014-0017. https://doi.org/10.1371/journal.pbio.0060003

Larkin, D. (2012). Misconceptions about Misconceptions: Preservice Secondary Science Teachers' Views on the Value and Role of Student Ideas. Science Education, 96, 927-959. https://doi.org/10.1002/sce.21022

Martin-Blas, T., \& Serrano-Fernandez, A. (2009). The Role of New Technologies in the Learning Process: Moodle as a Teaching Tool in Physics. Computers \& Education, 52, 35-44. https://doi.org/10.1016/j.compedu.2008.06.005

Moraru, S., Stoica, I., \& Popescu, F. F. (2011). Educational Software Applied in Teaching and Assessing Physics in High Schools. Romanian Reports in Physics, 63, 577-586.

Okorie, E. U., \& Agah, J. J. (2014). Teachers' Attitude towards the Use of Computer Software Package in Teaching Chemical Bonding. International Journal of Energy and Environmental Research, 2, 9-18.

Özmen, H. (2004). Some Student Misconceptions in Chemistry: A Literature Review of Chemical Bonding. Journal of Science Education and Technology, 13, 147-159. https://doi.org/10.1023/B:JOST.0000031255.92943.6d

Shah, I., \& Khan, M. (2015). Impact of Multimedia-Aided Teaching on Students' Academic Achievement and Attitude at Elementary Level. US-China Education Review, 5, 
349-360.

Snyder, T., \& Sullivan, H. (1995). Cooperative and Individual Learning and Student Misconceptions in Science. Contemporary Educational Psychology, 20, 230-235. https://doi.org/10.1006/ceps.1995.1015

Stice, J. (1987). Using Kolb's Learning Cycle to Improve Student Learning. Engineering Education, 77, 291-196.

Tatli, Z., \& Ayas, A. (2013). Effect of a Virtual Chemistry Laboratory on Students' Achievement. Educational Technology \& Society, 16, 159-170.

Thompson, F., \& Logue, S. (2006). An Exploration of Common Student Misconceptions in Science. International Education Journal, 7, 553-559. 